\title{
Distribution and Concentrations of Heavy Metals in Tropospheric Suspended Particulate Matter (PM10) In Nairobi City, Kenya
}

\author{
Faith Ndunge Mutua', Paul Njogu'1, Christopher Kanali ${ }^{2}$ \\ ${ }^{1}$ Institute of Energy and Environmental Technology, Nairobi, Kenya \\ ${ }^{2}$ School of Biomechanical and Environmental Engineering, JKUAT, Nairobi, Kenya \\ Email: faith.mutua1@gmail.com
}

How to cite this paper: Mutua, F.N. Njogu, P. and Kanali, C. (2021) Distribution and Concentrations of Heavy Metals in Tropospheric Suspended Particulate Matter (PM10) In Nairobi City, Kenya. Open Journal of Applied Sciences, 11, 899-907. https://doi.org/10.4236/ojapps.2021.118066

Received: June 30, 2021

Accepted: August 16, 2021

Published: August 19, 2021

Copyright () 2021 by author(s) and Scientific Research Publishing Inc. This work is licensed under the Creative Commons Attribution International License (CC BY 4.0).

http://creativecommons.org/licenses/by/4.0/

\begin{abstract}
Air pollution presents the greatest threat to human health and welfare in urban environments. Population growth, industrial activities, expanded transport system, vehicular traffic, poor road planning, poor land use and traffic congestion contribute to the problem. Particulate matter $\left(\mathrm{PM}_{2.5}\right.$ and $\mathrm{PM}_{10}$ ) has become the principal pollutants due to increased material use, energy demand and use as a result of global economic growth. This study assessed the levels of $\mathrm{PM}_{10}$ in ambient air and heavy metal composition in Nairobi city. Sampling sites were classified into three categories namely; controlled areas, industrial and residential areas as proscribed in the EMCA Air Quality Regulations, 2014. Portable Mini-Vol ambient air samplers were used for fine particulate monitoring. The concentrations of manganese, lead, and cadmium was determined in $\mathrm{PM}_{10}$ samples from all sampling sites. The lead concentration mean was $0.07 \pm 0.06 \mu \mathrm{g} / \mathrm{m}^{3}, 0.34 \pm 0.35 \mu \mathrm{g} / \mathrm{m}^{3}$ and $1.10 \pm 0.59$ $\mu \mathrm{g} / \mathrm{m}^{3}$ for residential, controlled and industrial areas respectively. Generally, all afternoons had high particulate matter while the lowest concentration levels of $\mathrm{PM}_{10}$ were recorded at night.
\end{abstract}

\section{Keywords}

Air Pollution, Heavy Metals, Tropospheric, Particulate Matter

\section{Introduction}

Air pollution is undesirable impacts from vehicular traffic and industrial manufacturers especially in the urban area. This is a serious health hazard because of the high prevalence of air pollution associated with diseases like cancer, asthma, 
eye problems and respiratory health problems in an urban environment especially in the young and elderly [1] [2]. One major cause of the increasing air pollution problem is an increased number of vehicles in urban environments as well as emissions from manufacturing industries [3] [4]. Particulate matter has adverse effects on human health, including mortality and morbidity caused by altered cardiovascular and respiratory function which is alarming in Kenya today. Kenya has an air quality regulation (2014). The purpose of this study is to assess the heavy metals concentrations in particulate matter in Nairobi city.

\section{Literature Review}

Airborne Particulates are finely divided solids and liquids suspended in air. The major sources of particulate can be natural or anthropogenic. Particulate matter (PM) can cause a variety of environmental problems, and can also have a significant impact on human health [5] [6] reports increased cases of hospitalization due of coronary artery disease, stroke and other atherosclerotic diseases caused by particulate matter.

In Kenya, major sources of particulate matter include transportation, stationary fuel combustion, industrial processes, agriculture and waste. Often, more consideration is given to the organic components of the particulate matter, but inorganic compounds may also be significant from a health point of view it has been reported that copper (and possibly iron) were significant contributors to the oxidative stress caused by fine particulate matter [6].

The fine particles are introduced to the atmosphere through the combustion of products as well as the formation of products in the atmosphere from gaseous pollutants as a result of secondary atmospheric chemical reactions. This particle poses a greater health risk than the larger particles since they can easily pass through into the lungs together with harmful chemicals in them that can cause different disease ailments [7]. Apart from the health impacts associated, this particle has a tendency to persist in the air for extended periods resulting in reduced visibility.

In Kenya the environmental management and coordination Act for Air Quality Standards was introduced recently (2014). The main object is determining the heavy metal concentration in different categories of sampling site.

\section{Materials and Methods}

\subsection{Introduction}

Minivol portable air sampler was used in sampling of particulate matter from the selected sites in the Nairobi County. The instrument consists of $\mathrm{PM}_{10}$ and $\mathrm{PM}_{2.5}$ sampling inlet. The $\mathrm{PM}_{10}$ masses on the filter were determined gravimetrically. The filters were conditioned at $20^{\circ} \mathrm{C}$ and $50 \%$ relative humidity prior to weighing. The PM samples collected were subjected to chemical analysis for subsequent determination of chemical composition of the PM. Particles containing the analytes of heavy metals, by drawing known volume of ambient air through 
filter and then dissolved in $\mathrm{HNO}_{3}$ and $\mathrm{H}_{2} \mathrm{O}_{2}$. Atomic absorption spectrometry (AAS) was used to analyze metal content in the sample after digestion.

\subsection{Sample Weighing and Gravimetric Analysis}

Filters before being placed in the sampler were pre-weighed on a high-precision scale in the laboratory to determine the weight of the filter without any dust deposit. The filter was then installed in the sampler. Ambient air was drawn in through the sampler head and filter media by a pump, similar to a vacuum cleaner motor so that airborne particulates were trapped on the filter. After sampling, the filter was returned to the laboratory and weighed again to determine how much dust was deposited on it. The difference between the two weights divided by the volume of air is the measurement that is used to determine 24-hour concentrations of $\mathrm{PM}_{10}$.

The room conditions were $25 \mathrm{EC} \pm 10 \mathrm{EC}$ and relative humidity $50 \% \pm 5 \%$. In Equation (1), $\mathrm{PM}_{10}$ is $\mathrm{PM}_{10}$ mass concentration, $10^{6}$ is conversion factor for grams to micrograms, $W_{\mathrm{f}}$ is final weight of exposed filter, $W_{\mathrm{i}}$ is initial weight of unexposed filter and $V$ is volume of air sampled.

$$
P M_{10}=\left(W_{i}-W_{f}\right) 10^{6} / \mathrm{V}
$$

The key focus of the study was the spatial and temporal distribution of PM chemical composition. Daily concentration of each component for each site were calculated. The amount of dust in Nairobi County was measured to determine the levels and concentrations in terms of heavy metals.

\subsection{Sample Digestion, Analysis and Calculation}

To determine the heavy metal (lead, cadmium and manganese) concentration, $\mathrm{PM}_{10}$ samples were digested using $2 \mathrm{ml}$ of concentrated Nitric acid and $5 \mathrm{ml}$ of Hydrochloric acid. The solutions were heat on electric hot plate at a temperature of $90^{\circ} \mathrm{C}-95^{\circ} \mathrm{C}$ (not to boil) until the volume was $15-20 \mathrm{ml}$ (3). The solution was allowed to cool and adjusted to $100 \mathrm{ml}$ with distilled water. The concentrations of lead, cadmium and manganese was determined using Atomic Absorption spectrometer.

\section{Results and Discussion}

The study area was Nairobi City, the capital city of Kenya (Figure 1). It has a population of 4,735,000 with an area of $696 \mathrm{~km}^{2}$. The city has a weather patterns of $25^{\circ} \mathrm{C}$, wind SE at $6 \mathrm{~km} / \mathrm{h}$, and $44 \%$ humidity, it lies at the southern end of Kenya's agricultural heartland, $1.19^{\circ}$ south of the equator and $36.9^{\circ}$ east of meridian and 1600 to 1850 masl. The average daily temperature is $29^{\circ} \mathrm{C}$ and $24^{\circ} \mathrm{C}$ during dry and wet seasons, respectively, with constant 12 hours' daylight [8].

Table 1 presents the different categories and description of sampling sites as classified in the EMCA 2014 (Air Quality Regulation). There are three categories; Residential, Controlled and industrial designated areas with different set permissible standards for each category. 
Table 1. Description of sampling sites.

\begin{tabular}{|c|c|c|c|}
\hline $\begin{array}{c}\text { EMCA Air Quality } \\
\text { Regulation } 2014 \text { Categories }\end{array}$ & Category definition & Identified sampling sites & Site description \\
\hline Industrial area & Industrial designated areas & $\begin{array}{c}\text { Industrial area road C } \\
\text { Industrial area-Enterprise road }\end{array}$ & $\begin{array}{l}\text { Manufacturing zone, Unpaved } \\
\text { roads, Big trucks on the road }\end{array}$ \\
\hline $\begin{array}{l}\text { Residential, } \\
\text { rural and other Areas }\end{array}$ & Residential designated areas & Kayole and Embakasi & $\begin{array}{c}\text { Unpaved Roads, tall residential } \\
\text { buildings, Burning tyres, } \\
\text { High traffic }\end{array}$ \\
\hline Controlled Areas & $\begin{array}{c}\text { Residential areas, Hospitals, } \\
\text { National Parks, Reserves and } \\
\text { Sanctuaries, conservation areas, } \\
\text { conservation areas, Central Business } \\
\text { Districts Any other area declared } \\
\text { by the Authority from time to time }\end{array}$ & $\begin{array}{l}\text { Moi Avenue Primary School } \\
\text { Old Nation Round about (Koja), } \\
\text { Ngara Jua Kali Area, Pangani Round } \\
\text { About, Museum Hill Interchanger }\end{array}$ & $\begin{array}{l}\text { Tall building, traffic congestion, } \\
\text { few unpaved areas, high day } \\
\text { and low night population } \\
\text { Unpaved roads, temporally } \\
\text { buildings, tall buildings } \\
\text { and high traffic }\end{array}$ \\
\hline
\end{tabular}

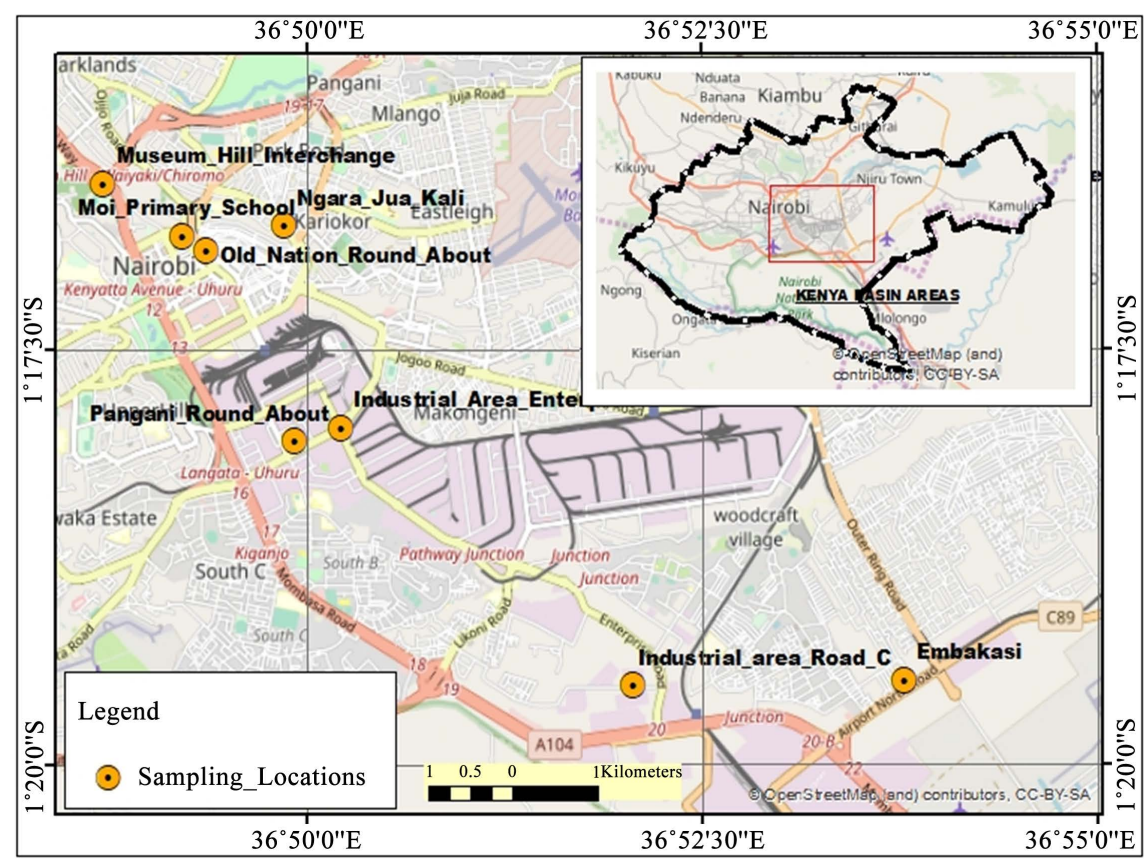

Figure 1. Shows the sampling site in the residential, controlled and industrial area with the Nairobi city county.

Figure 2 illustrates the concentration of Lead, Cadmium and Manganese from the industrial sampling sites. High concentrations of lead recorded while cadmium had the lowest concentrations. The sampling site being an industrial manufacturing zone, the source of lead can be associated with smelting, manufacturing and recycling activities, and, in some cases, the use of leaded paint, leaded gasoline, and leaded aviation fuel.

Figure 3 presents three heavy metals (Lead, Cadmium and Manganese) which have been classified as carcinogenic. The sampling sites are along main roads within the city and also near the industrial zones hence high traffic. This can explain the high manganese concentrations recorded. Lead traces were also 


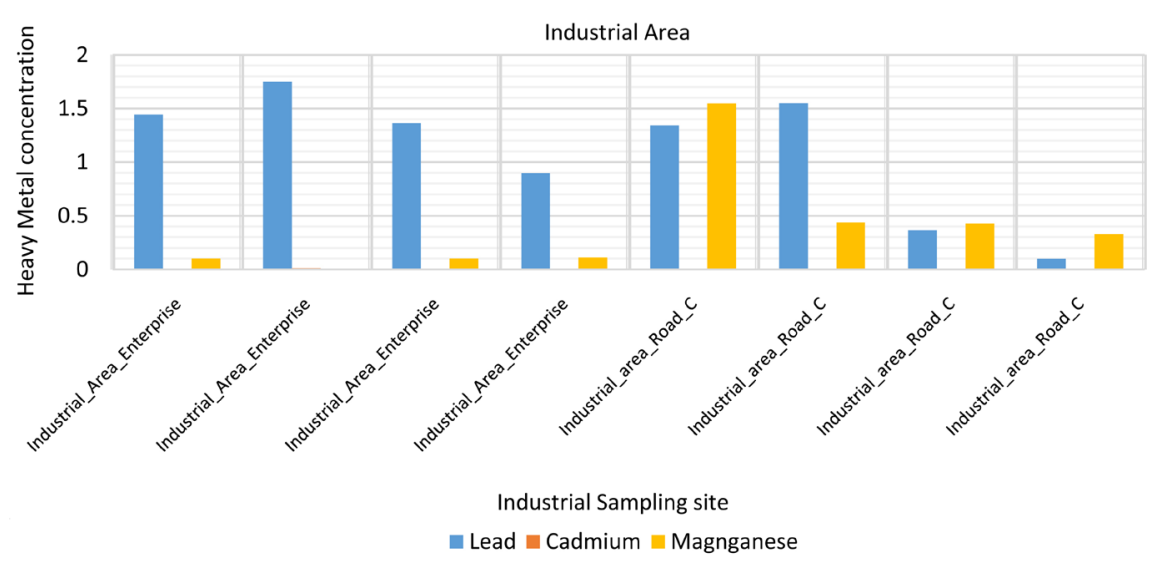

Figure 2. Heavy metal (Lead, Cadmium and Manganese) concentration in Industrial Area.

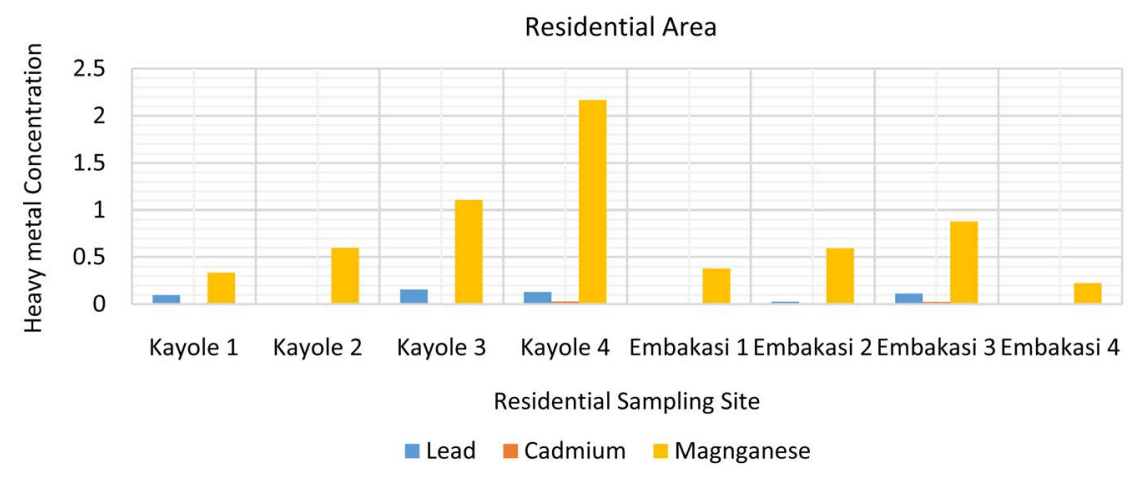

Figure 3. Heavy metal (Lead, Cadmium and Manganese) concentration in Residential Area.

recorded in all samples while cadmium was only traced in few samples from the residential areas. The sources of cadmium to the environment are related to its application in industry as a corrosive reagent, as well as its use as a stabilizer in PVC products, color pigments, and Ni-Cd batteries. Cadmium is a pollutant introduced in the environment as a result of the rapid development of industries and modern technologies.

Figure 4 demonstrates lead, Cadmium and Manganese concentration in the controlled area as categorized by EMCA 2014 (Air quality Regulation). Despite high manganese and lead concentration cadmium was also recorded almost all the sites in the controlled areas.

Table 2 shows the heavy metal concentration levels of heavy metals in Residential, Controlled and industrial areas. Manganese has the highest levels. The permissible levels for the metals are not provided in the regulation except lead (Table 3).

Figure 5 shows lead concentration in all sampling sites compared to the set standards (EMCA2014 and EPA Standards). In all the cases, the concentration of lead was above the EPA permissible levels but within the EMCA 2014 standards. The EPA has uniform (one value) for all three categories of sampling sites while EMCA 2014 has different values as standard for each category. 


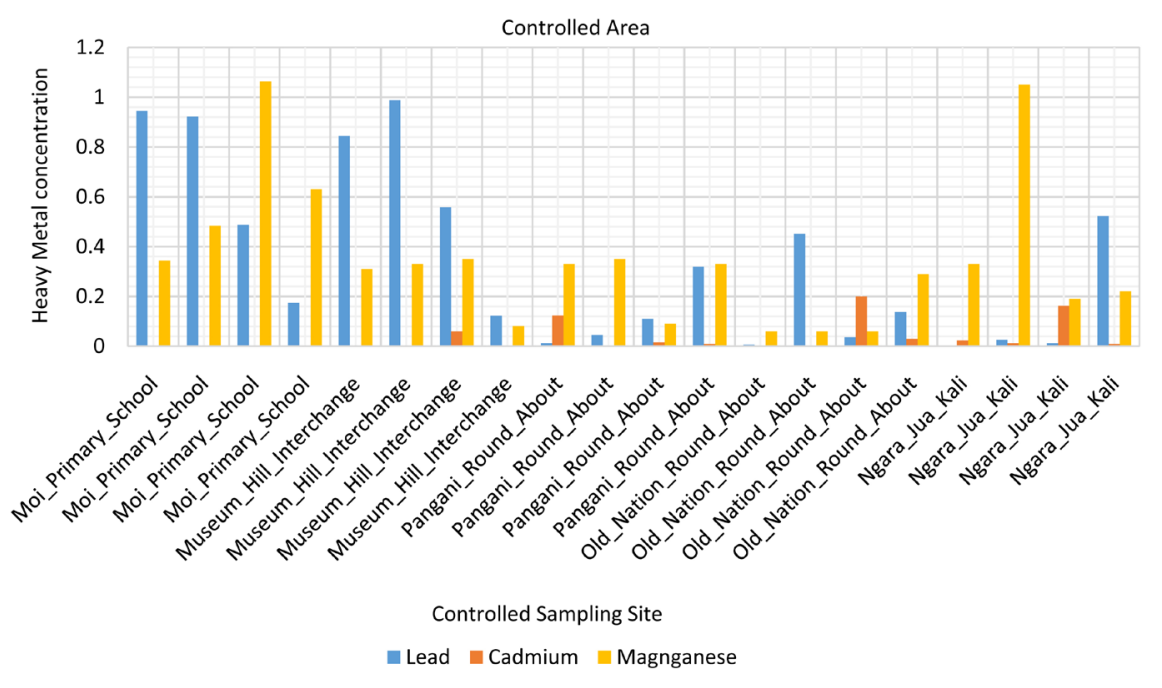

Figure 4. Heavy metal (lead, cadmium and manganese) concentration in controlled area.

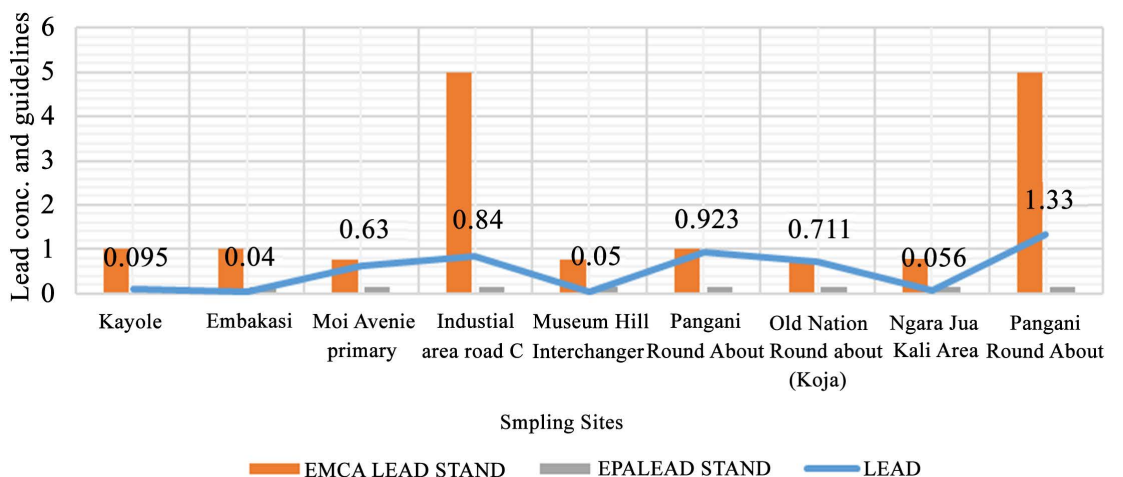

Figure 5. Comparing lead concentration in ambient air with EMCA and EPA standards.

Table 2. Concentration of the analysed heavy for residential, controlled and industrial area.

\begin{tabular}{cccc}
\hline & Lead & Cadmium & Manganese \\
\hline Residential & $0-0.156$ & $0-0.03$ & $0.2255-2.17$ \\
Controlled & $0.0011-0.988$ & $0-0.2$ & $0.06-1.0624$ \\
Industrial & $0.099-1.75$ & $0-0.0123$ & $0.001-1.549$ \\
\hline
\end{tabular}

Table 3. Heavy metal mean values for the three site categories.

\begin{tabular}{cccc}
\hline & \multicolumn{3}{c}{ Area } \\
\cline { 2 - 3 } Heavy metal & Residential area & Controlled area & \multirow{2}{*}{ Industrial area } \\
\cline { 2 - 3 } & & Mean concentration $\left(\mu \mathrm{g} / \mathrm{m}^{3}\right)$ & \\
\hline Lead & $0.066 \pm 0.064$ & $0.336 \pm 0.354$ & $1.102 \pm 0.592$ \\
Cadmium & $0.007 \pm 0.013$ & $0.032 \pm 0.058$ & $0.002 \pm 0.004$ \\
Manganese & $0.785 \pm 0.630$ & $0.347 \pm 0.284$ & $0.381 \pm 0.500$ \\
\hline
\end{tabular}


Generally, Manganese and lead were relatively high in both controlled and industrial areas. Manganese was recorded highest in the residential area while lead was the highest in samples from the industrial areas. More than three quarters of global lead consumption is for the manufacture of lead-acid batteries for motor vehicles. The high levels of lead recorded in the industrial area can associated with manufacturing and use of lead products like, pigments, paints, solder, stained glass, lead crystal glassware, ammunition, ceramic glazes, jewellery, toys, cosmetics and recycling materials containing lead within the industrial zone.

Figure 6 shows spatial distribution of heavy metal concentrations. Manganese concentration was much more significant with the highest concentration of most of the samples in most of the sampling sites.

Lead is the only metal with set permissible standards in both EPA and EMCA (Air Quality Regulations 2014). Arsenic is considered to be poison while lead is carcinogenic, hence, high presence of the two metals in ambient air indicates high health diseases that are associated with lead and arsenic [9] [10] [11]. From previous studies most of metals analysed in this study are referred to be carcinogenic. Both the EPA and EMCA do not provide guideline values for most of the carcinogenic components, such as metals, nor their compounds in particulate matter.

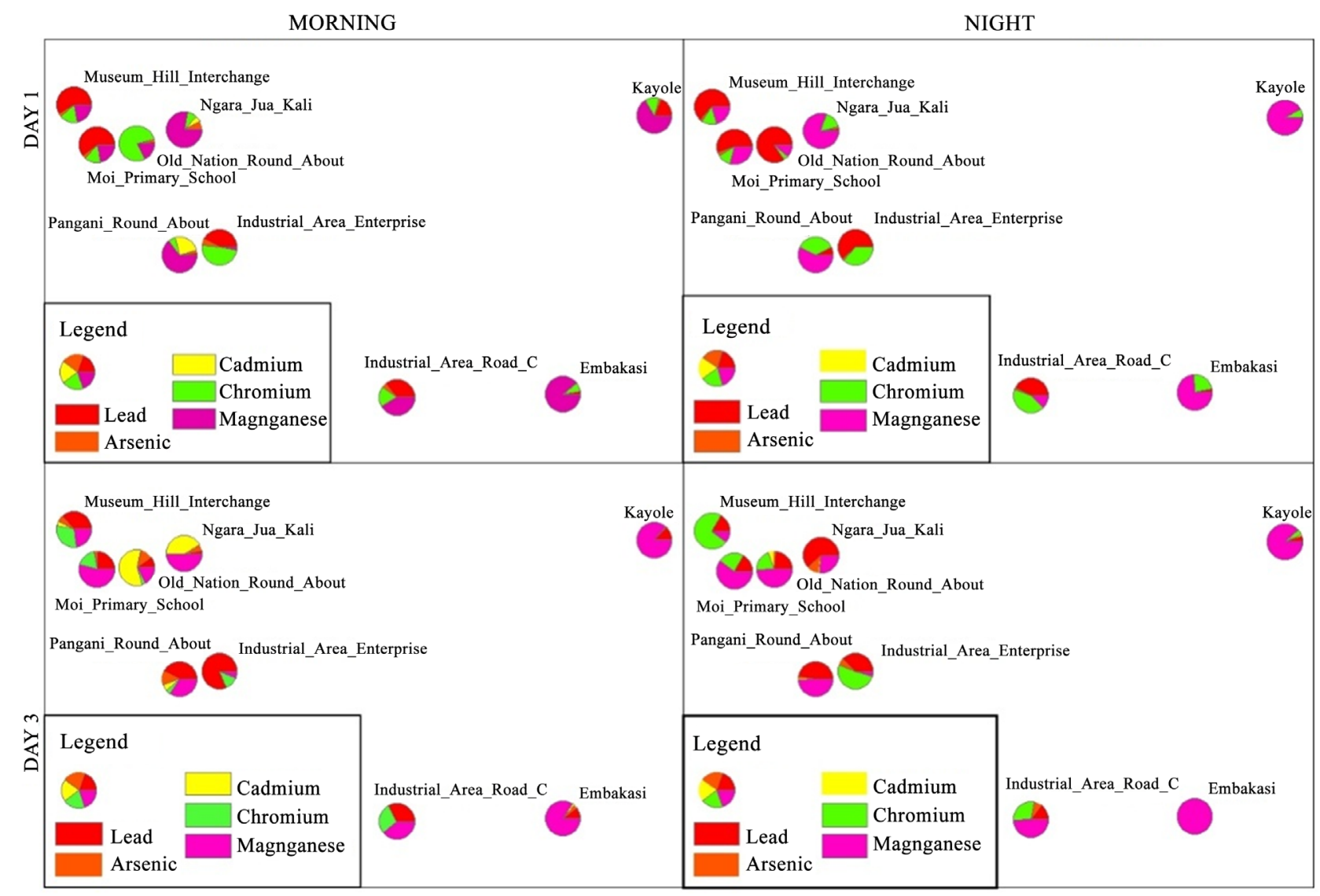

Figure 6. Spatial distribution of heavy metals at the sampling sites during the day and night for the three days of sampling. 
The metal composition of the $\mathrm{PM}_{10}$ contained significant amount of Lead, manganese and cadmium which are carcinogenic. The permissible levels of the metallic components or their compounds are not addressed in both EPA and EMCA standards except lead. The presence of lead in the respirable particulate matter $(<10 \mu \mathrm{m})$ poses high risks of health to human in the Nairobi city and its environs. People can become exposed to lead through occupational and environmental sources. This mainly results from inhalation of lead particles generated by burning materials containing lead during smelting, recycling, stripping leaded paint, and using leaded gasoline or leaded aviation fuel and also ingestion of lead-contaminated dust, water (from leaded pipes), and food (from lead-glazed or lead-soldered containers). Cadmium was classified by the International Agency for Research on Cancer (IARC) as a carcinogenic agent when inhaled.

Understanding the composition of ambient air organic and inorganic particulate matter is essential in predicting its effects on public health. Specification and quantification is very crucial in determining the effects [12]. The set standards both EPA and EMCA have no guide lines values for cadmium and manganese standards in the ambient air. This shows that the cadmium and manganese emitters are not aware of what levels are allowed in the environment, which may lead to high concentration impacting negatively on the environment and on human health. The same case happens with most of the inorganic materials and metals in which they are not specified in the standards. This can lead to adverse impacts including different diseases associated with inhalable respirable particulate matter $(<10 \mu \mathrm{m})$ with high levels of the metals on the Nairobi city dwellers.

\section{Conclusion}

The highest heavy metal concentration in the particulate matter was found to be, manganese in residential areas and lead in the industrial areas. There are set standards of the permissible levels of manganese and cadmium. Lead concentration levels of $1.33 \mu \mathrm{g} / \mathrm{m}^{3}$ were above the EPA standards but were within EMCA 2014 standards in controlled areas.

\section{Acknowledgements}

Authors acknowledge the National Commission for Science, Technology and Innovation (NACOSTI) for financial support and everyone who contributed to the success of the study.

\section{Conflicts of Interest}

The authors declare no conflicts of interest regarding the publication of this paper.

\section{References}

[1] Brook, R.D., Franklin, B., Cascio, W., Hong, Y., Howard, G., Lipsett, M., Luepker, R., Mittleman, M., Samet, J., Smith, S.C. and Jr Tager, I. (2004) Expert Panel on 
Population and Prevention Science of the American Heart Association. Air Pollution and Cardiovascular Disease, 109, 2655-2671. https://doi.org/10.1161/01.CIR.0000128587.30041.C8

[2] Gatebe, C.K., Kinyua, A.M., Mangala, M.J., Kwach, R., Njau, L.N., Mukolwe, E.A. and Maina, D.M. (1996) Determination of Suspended Particulate Matter of Major Significance to Human Health Using Nuclear Techniques in Kenya. Journal of Radioanalytical and Nuclear Chemistry, 203, 125-134.

https://doi.org/10.1007/BF02060387

[3] GOK (2004) Ministry of Transport and Communications. "Recommendations on Integrated National Transport Policy": Moving a Working Nation. Government of Kenya, Nairobi, 2004.

[4] GOK (2010) Ministry of Transport. Sessional Paper on Integrated National Transport Policy. Government of Kenya, Nairobi, 2010.

[5] Zanobetti, A., Franklin, M., Koutrakis, P. and Schwartz, J. (2009) Fine Particulate Air Pollution and Its Components in Association with Cause-Specific Emergency Admissions. Environmental Health, 8, Article No. 58. https://doi.org/10.1186/1476-069X-8-58

[6] Baulig, A., Poirault, J.J., Ausset, P., Schins, R., Shi, T., Baralle, D., Dorlhene, P., Meyer, M., Lefevre, R., Baeza-Squiban, A. And Marano, F. (2004) Physicochemical Characteristics and Biological Activities of Seasonal Atmospheric Particulate Matter Sampling in Two Locations of Paris. Environmental Science \& Technology, 38, 5985 5992. https://doi.org/10.1021/es049476z

[7] Ibald-Mulli, A., Timonen, K.L., Peters, A., Heinrich, J., Wolke, G., Lanki, T., Buzorius, G., Kreyling, W.G., de Hartog, J., Hoek, G., ten Brink, H.M. and Pekkanen, J. (2004) Effects of Particulate Air Pollution on Blood Pressure and Heart Rate in Subjects with Cardiovascular Disease: A Multicenter Approach. Environmental Health Perspectives, 112, 369-377. https://doi.org/10.1289/ehp.6523

[8] Japanese International Cooperation Agency (JICA) (2006) Final Report. Tokyo: JICA; 2006. The Study on a Master Plan for Urban Transport in the Nairobi Metropolitan Area in the Republic of Kenya.

[9] Bell, M.L., Dominici, F., Ebisu, K., Zeger, S.L. and Samet, J.M. (2007) Spatial and Temporal Variation in PM (2.5) Chemical Composition in the United States for Health Effects Studies. Environmental Health Perspectives, 115, 989-995.

https://doi.org/10.1289/ehp.9621

[10] Lu, D., Xu, J., Yang, D. and Zhao, J. (2017) Spatio-Temporal Variation and Influence Factors of PM2.5 Concentrations in China from 1998 to 2014. Atmospheric Pollution Research, 8, 1151-1159. https://doi.org/10.1016/j.apr.2017.05.005

[11] Lai, S., Zhao, Y., Ding, A., Zhang, Y., Song, T., Zheng, J., Song, T., Zheng, J., Lee, S. and Zhong, L. (2016) Characterization of PM2.5 and the Major Chemical Components during a 1-Year Campaign in Rural Guangzhou, Southern China. Atmospheric Research, 167, 208-215. https://doi.org/10.1016/j.atmosres.2015.08.007

[12] Gatari, M.J., Wagner, A. and Boman, J. (2005) Elemental Composition of Tropospheric Aerosols in Hanoi, Vietnam and Nairobi, Kenya. Science of the Total Environment, 341, 241-249. https://doi.org/10.1016/j.scitotenv.2004.09.031 